Research Article

\title{
A Comparative Study of Health-related Quality of Life among Working and Non-working Married Women in an Urban area in South Goa
}

\author{
Shefalee Pai Vernekar', Hemangini K Shah $^{2}$ \\ ${ }^{1}$ Post Graduate Student, ${ }^{2}$ Assistant Professor, Department of Preventive and Social Medicine, Goa Medical College. \\ DOI: https://doi.org/10.24321/2454.325X.201914
}

\section{I $\quad \mathbf{N} \quad \mathbf{F} \quad \mathbf{O}$}

\section{Corresponding Author:}

Shefalee Pai Vernekar, Department of Preventive and Social Medicine, Goa Medical College.

E-mail Id:

shefa_pv@yahoo.co.in

Orcid Id:

https://orcid.org/0000-0002-5487-1878

How to cite this article:

Vernekar SP, Shah HK. A Comparative Study of Health-related Quality of Life among Working and Non-working Married Women in an Urban area in South Goa. Int J Preven Curat Comm Med 2019; 5(3): 11-17.

Date of Submission: 2019-02-19

Date of Acceptance: 2019-12-03

\section{$\begin{array}{llllllll}\mathbf{A} & \mathbf{B} & \mathbf{S} & \mathbf{T} & \mathbf{R} & \mathbf{A} & \mathbf{C} & \mathbf{T}\end{array}$}

Background: It is believed that job is one of the most effective factors in improving a women's quality of life. However, working women often suffer from physical as well as psychological health problems due to dual responsibilities they have to perform i.e. at workplace as well as maintaining their traditional roles at home. This pressure at workplace and house may have an influence health-related quality of a woman.

Objectives: This study was conducted with the following objectives:

- To determine the health related quality of life among working and non working women.

- To compare the quality of life among working and non working women.

- To study certain factors associated with health related quality of life among them.

Materials and Methods: This was a cross sectional study conducted among 50 working and 50 non working married women between 25 to 45 years of age, in an urban area in South Goa. Simple random sampling was used to select the households and data was collected through face to face interview and the health related quality of life was assessed using SF-36 questionnaire. Data was summarized using frequencies, percentages, means and standard deviations. Student's T test was used to compare the quality of life scores between working and non-working women.

Result: The working women had higher SF-36 scores in all the 8 categories. The mean score of general health domain in working women was $63.80 \pm 15.17$ among working women compared to $50.20 \pm 10.50$ among non working women $(p<0.001)$. Similarly in the domain of role limitations due to physical health, working women had a significantly higher mean score $(90.50 \pm 15.06)$ compared to non working women $(58.67 \pm 23.69)$.This implied that working women had better quality of life in comparison to non working women. The lowest means were in energy/fatigue category.

Conclusion: Findings of this study suggest working women to have better quality of life. This may be due to a sense of self esteem, security and independence of a working woman.

Keywords: Working, Women, Health, Quality of Life

International Journal of Preventive, Curative \& Community Medicine (ISSN: 2454-325X) 


\section{Introduction}

Woman is an integral part of our families and societies; and the health of a woman reflects the overall health of the community. Over the past few years, women's attitude towards the traditional roles has been changing and many have taken up the dual responsibilities of managing job as well as household work. "The number of working women has increased compared to a decade before due to the increase in educational and job opportunities as well as due to financial demands of managing households". ${ }^{1}$ For the social, political and economic improvement of women's status, empowerment of women is of utmost importance. ${ }^{2}$ Many studies have reported married working women to have better health despite having dual roles and responsibilities. $^{3}$

The World Health Organization (WHO) defines health as a "state of complete physical, mental and social wellbeing and not merely the absence of disease". "Health-related quality of life is an individual's perceived physical and mental health over time". ${ }^{4}$ The WHO defines quality of life as "an individual's perception of their position in life in context of the culture and value systems in which they live and in relation to their goals, expectations, standards and concerns". ${ }^{5}$

It is believed that job is one of the most effective factors in improving a women's quality of life. ${ }^{6}$ However, working women often suffer from physical as well as psychological health problemsdue to the dual responsibilities at workplace as well as maintaining their traditional roles at home that they have to perform. ${ }^{7}$ This pressure at workplace and house may have an influenceon the health-related quality of a woman. On the other hand, working women may also experience financial independence, increased self esteem and better social life.

\section{Objectives}

This study was conducted with the following objectives:

- To determine the health related quality of life among working women and housewives.

- To compare the quality of life among working women and housewives.

- To study certain factors associated with health related quality of life among them.

\section{Materials and Methods}

This cross sectional study was conducted in an urban area in South Goa.

\section{Study Setting}

This study was conducted in ward number 8 under Madgao Municipality in South Goa. There are 25 wards under Madgao Municipality. By lottery method one number (between 1 to 25) was chosen randomly and it turned out to be 8 . Hence Ward number 8 under the Madgao municipality was selected for the present study.

\section{Study Duration}

The present study was conducted over duration of two months from $1^{\text {st }}$ November 2017 - 31 ${ }^{\text {st }}$ December 2017.

\section{Sample Size}

A sample size of 50 working women and 50 non working women was considered for the study. The following formula was used to derive at the above sample size using mean and standard deviations of mental health score from a study by Zalodiya $\mathrm{K}$ et al. ${ }^{8}$

$n=2(z a+z \beta)^{2} S^{2}$ where $z a=1.96, z \beta=0.84$,

$\left(\mu_{1}-\mu_{2}\right)^{2}$ Mean $(\mu): \mu_{1}=73.5, \mu_{2}=68$

Standard deviation $(S): S_{1}=9.2, S_{2}=10.5$

\section{Study Subjects}

- Ever married women, working for at least last 6 months and non-working

- Women residing in the study area for more than 6 months.

- Age: 25 to 45 years

\section{Exclusion Criteria}

- Critically ill patients, pregnant

- Participants who did not give consent.

The following definitions were considered:

Working Woman: ${ }^{9}$ Is a woman who earns a salary, wages, or other income through regular employment usually outside home.

Non working Woman: is a woman who does not earn any income, wages or salary and does only household chores.

\section{Data Collection}

The households from Ward number 8 were selected by simple random to obtain the desired sample size. If any house was found locked in spite of two attempts, then the locked house was excluded and procedure of simple random sampling was repeated till desired sample size was reached. If during data collection, there was more than one woman in a house fitting the inclusion criteria, only one of them was chosen randomly and included in the present study. Informed consent was taken from each participantin their local language.

Data collection tool:Data was collected by face to face interview. The following data tools were used for data collection:

1. Predesigned questionnaire containing sociodemographic, medical and work-related information 
2. SF-36 questionnaire to assess health-related quality of life

\section{SF-36 Questionnaire ${ }^{10}$}

The SF-36 (36 item Short Form survey) was developed by the RAND Corporation as a part of the Medical Outcomes Survey to assess the quality of life. The SF-36 questionnaire had 36 questions, which were then grouped into 8 categories:

- Physical functioning

- Role limitations due to physical health

- Role limitations due to emotional problems

- Energy/fatigue

- Emotional well-being

- Social functioning

- Pain

- General health

Each scale is directly transformed into a 0-100 scale on the assumption that each question carries equal weight. Higher the score, the less is the disability. The grouping of each question into scales and scoring was done based on the instructions provided by the RAND 36-item Health Survey.

\section{Data Analysis}

The data from the duly filled questionnaires was coded and entered in Excel spreadsheet. Data was then analyzed in
SPSS version 22. Data was summarized using frequencies, percentages, means and standard deviations. Student's T test was used to compare the quality of life scores between working and non-working women. A p value $<0.05$ was considered as statistically significant.

\section{Result}

The mean age of working women was $34.62 \pm 6.23$ years and that of non-working women was $35.70 \pm 5.97$ years. Majority of the study participants were Hindus. The working and non-working women had similar characteristics with respect to socio-demographic characteristics a(s shown in Table ).

$72 \%$ of working and non-working women stayed in a nuclear family with majority having two children. $10 \%$ working women and $18 \%$ non-working women had their spouses abroad (Refer Table 2).

\section{Work-related Characteristics of Working Women}

$62 \%$ of the working women worked because they had some financial constraint or to contribute to the family income whereas the remaining $38 \%$ worked due to their personal interest. 54\% of them worked for a private company and $30 \%$ had government jobs. $84 \%$ of them had regular duty hours and only $10 \%$ had rotatory which included night shifts (Refer Figure 1, Figure 2 and Table 3).

Table I.Socio-demographic characteristics of study participants

\begin{tabular}{|c|c|c|c|c|c|}
\hline & \multirow{2}{*}{ Variable } & \multicolumn{2}{|c|}{ Working women $(\mathrm{N}=50)$} & \multicolumn{2}{|c|}{ Non-working women $(\mathrm{N}=50)$} \\
\hline & & No. & $\%$ & No. & $\%$ \\
\hline \multirow{4}{*}{ Age Group } & 25 - 29 years & 13 & 26 & 10 & 20 \\
\hline & $30-34$ years & 13 & 26 & 13 & 26 \\
\hline & $35-39$ years & 12 & 24 & 13 & 26 \\
\hline & $40-45$ years & 12 & 24 & 14 & 28 \\
\hline \multirow{3}{*}{ Religion } & Hindu & 24 & 48 & 31 & 62 \\
\hline & Christian & 23 & 46 & 16 & 32 \\
\hline & Muslim & 03 & 06 & 03 & 06 \\
\hline \multirow{5}{*}{ Education } & Illiterate & 02 & 04 & 07 & 14 \\
\hline & Primary & 10 & 20 & 13 & 26 \\
\hline & High school & 11 & 22 & 14 & 28 \\
\hline & Higher secondary & 15 & 30 & 13 & 26 \\
\hline & Graduate or higher & 12 & 24 & 03 & 06 \\
\hline \multirow{2}{*}{ Marital Status } & Married & 48 & 96 & 46 & 92 \\
\hline & Widow/separated/divorced & 02 & 04 & 04 & 08 \\
\hline \multirow{5}{*}{$\begin{array}{l}\text { Socio-economic } \\
\text { class using } \\
\text { Modified } \\
\text { BG Prasad } \\
\text { Classification }\end{array}$} & Class I & 40 & 80 & 38 & 76 \\
\hline & Class II & 04 & 08 & 10 & 20 \\
\hline & Class III & 04 & 068 & 02 & 04 \\
\hline & Class IV & 02 & 04 & 00 & 00 \\
\hline & Class V & 00 & 00 & 00 & 00 \\
\hline
\end{tabular}


Table 2.Family-related characteristics of study participants

\begin{tabular}{|c|c|c|c|c|c|}
\hline \multirow{2}{*}{\multicolumn{2}{|c|}{ Variable }} & \multicolumn{2}{|c|}{ Working women $(\mathrm{N}=50)$} & \multicolumn{2}{|c|}{ Non-working women $(\mathrm{N}=50)$} \\
\hline & & No. & $\%$ & No. & $\%$ \\
\hline \multirow{2}{*}{ Type of family } & Nuclear & 36 & 72 & 36 & 72 \\
\hline & Joint or three generation & 14 & 28 & 14 & 28 \\
\hline \multirow{4}{*}{ Number of children } & None & 04 & 08 & 04 & 08 \\
\hline & One child & 15 & 30 & 20 & 40 \\
\hline & Two children & 29 & 58 & 26 & 52 \\
\hline & Three or more children & 02 & 04 & 00 & 00 \\
\hline \multirow{3}{*}{$\begin{array}{c}\text { Age of child less than } \\
5 \text { years }\end{array}$} & Yes & 14 & 28 & 15 & 30 \\
\hline & No & 32 & 64 & 31 & 62 \\
\hline & Not applicable & 04 & 08 & 04 & 08 \\
\hline \multirow{3}{*}{$\begin{array}{c}\text { Critical academic event } \\
\text { of child }\end{array}$} & Yes & 04 & 08 & 03 & 06 \\
\hline & No & 42 & 84 & 43 & 86 \\
\hline & Not applicable & 04 & 08 & 04 & 08 \\
\hline \multirow{3}{*}{$\begin{array}{l}\text { Spouse is abroad/ } \\
\text { often out of station }\end{array}$} & Yes & 05 & 10 & 09 & 18 \\
\hline & No & 43 & 86 & 37 & 74 \\
\hline & Not applicable & 02 & 04 & 04 & 08 \\
\hline \multirow{3}{*}{$\begin{array}{c}\text { Tobacco/ alcohol } \\
\text { addiction in spouse }\end{array}$} & Yes & 14 & 28 & 12 & 24 \\
\hline & No & 34 & 68 & 34 & 68 \\
\hline & Not applicable & 02 & 04 & 04 & 08 \\
\hline \multirow{2}{*}{$\begin{array}{l}\text { Bed-ridden/ seriously- } \\
\text { ill family member }\end{array}$} & Yes & 02 & 04 & 03 & 06 \\
\hline & No & 48 & 96 & 47 & 94 \\
\hline \multirow{2}{*}{ Household-help } & Yes & 11 & 22 & 17 & 34 \\
\hline & No & 39 & 78 & 33 & 66 \\
\hline
\end{tabular}

Table 3.Work-related characteristics of study participants

\begin{tabular}{|c|c|c|c|}
\hline \multirow{2}{*}{\multicolumn{2}{|c|}{ Variable }} & \multicolumn{2}{|c|}{ Working women $(\mathrm{N}=50)$} \\
\hline & & No. & $\%$ \\
\hline \multirow{3}{*}{ Work timings } & Regular duty hours & 42 & 84 \\
\hline & Shift-pattern & 06 & 12 \\
\hline & Hourly/contract basis & 02 & 04 \\
\hline \multirow{3}{*}{ Distance to work } & Less than $10 \mathrm{kms}$ & 02 & 04 \\
\hline & $10-20 \mathrm{kms}$ & 28 & 56 \\
\hline & More than $20 \mathrm{kms}$ & 20 & 40 \\
\hline \multirow{3}{*}{ Mode of travel to work } & Walking & 02 & 04 \\
\hline & Public transport & 12 & 24 \\
\hline & Own vehicle & 36 & 72 \\
\hline
\end{tabular}

\section{Comparison of Quality of Life among working and non-workingwomen}

Comparison of SF-36 scores for both the groups is depicted below in Table 4. The results show that working women have a better health-related quality of life compared to non working women. Except for physical functioning, the difference in scores of all other scales was statistically 
significant. The lowest means were in energy/ fatigue category for working women whereas for the non working women it was in the emotional well-being category. Higher scores suggest a better quality of life. Highest scores were in the role limitations due to physical health category for working women whereas for non-working women highest scores were in the category of physical functioning.

\section{Association of Health-related Quality of Life with Certain Variables}

SF-36 scores of women were compared with respect to certain variables such as education status of the women, presence of any household help at home and a child having any critical academic event such as a final exam in the upcoming year. None of the scores were found to be significantly different. However, those women whose child had some critical academic event had lower scores suggesting lower quality of life. Also, when the scores of working women who cited financial problems as the reason for working were compared to those who worked because of personal interest, it was found that the former had poorer scores. The above findings indicate that the above variables did not have a significant effect on quality of life of women. The difference in SF-36 scores between working and non working women could probably be due the working profile of the working women (Refer Table 5).

Table 4.Health-related of quality of life scores among study participants

\begin{tabular}{|c|c|c|c|c|c|c|}
\hline \multirow{2}{*}{ SF-36 scores } & \multicolumn{2}{|c|}{ Working women $(\mathrm{N}=50)$} & \multicolumn{2}{|c|}{ Non-working women $(\mathrm{N}=50)$} & \multirow{2}{*}{ T-test } & \multirow{2}{*}{ p-value } \\
\hline & Mean & SD & Mean & SD & & \\
\hline Physical functioning & 60.80 & 36.24 & 60.70 & 14.49 & 0.018 & 0.986 \\
\hline $\begin{array}{l}\text { Role limitations due to } \\
\text { physical health }\end{array}$ & 90.50 & 15.06 & 58.67 & 23.69 & 7.994 & $<0.001$ \\
\hline $\begin{array}{l}\text { Role limitations due to } \\
\text { emotional problems }\end{array}$ & 88.67 & 19.76 & 54.00 & 30.03 & 6.818 & $<0.001$ \\
\hline Energy/fatigue & 55.40 & 8.07 & 46.00 & 6.92 & 6.250 & $<0.001$ \\
\hline Emotional wellbeing & 59.28 & 16.65 & 42.08 & 9.87 & 6.282 & $<0.001$ \\
\hline Social functioning & 66.25 & 16.99 & 49.25 & 15.85 & 5.173 & $<0.001$ \\
\hline Pain & 70.05 & 8.31 & 57.05 & 20.90 & 4.087 & $<0.001$ \\
\hline General health & 63.80 & 15.17 & 50.20 & 10.50 & 5.174 & $<0.001$ \\
\hline
\end{tabular}

Table 5.Comparison of mean SF-36 scores among study participants with respect to certain variables

$(\mathrm{N}=100)$

\begin{tabular}{|c|c|c|c|c|c|}
\hline \multirow{2}{*}{\multicolumn{2}{|c|}{ Variables }} & \multicolumn{2}{|c|}{ SF-36 scores } & \multirow{2}{*}{ T-test } & \multirow{2}{*}{ p-value } \\
\hline & & Mean & SD & & \\
\hline \multirow{2}{*}{ Education of High school or more } & Yes & 90.10 & 11.27 & \multirow{2}{*}{0.38} & \multirow{2}{*}{0.704} \\
\hline & No & 91.00 & 10.34 & & \\
\hline \multirow{2}{*}{ Household help } & Yes & 88.93 & 13.03 & \multirow{2}{*}{0.83} & \multirow{2}{*}{0.408} \\
\hline & No & 90.96 & 10.06 & & \\
\hline \multirow{2}{*}{$\begin{array}{l}\text { Critical academic event of any } \\
\text { child }\end{array}$} & Yes & 83.29 & 10.26 & \multirow{2}{*}{1.80} & \multirow{2}{*}{0.075} \\
\hline & No & 90.92 & 10.86 & & \\
\hline \multirow{2}{*}{$\begin{array}{l}\text { Financial constraint as reason for } \\
\text { working among working women }\end{array}$} & Yes & 87.42 & 12.05 & \multirow{2}{*}{0.56} & \multirow{2}{*}{0.576} \\
\hline & No & 89.32 & 10.72 & & \\
\hline
\end{tabular}

\section{Discussion}

In the present study working women had better quality of life scores in all the 8 categories compared to nonworking women. Except for physical functioning, all other parameters showed a statistically significant difference. This suggests that working had an effect on improving the quality of life of women.
In spite of being at home and not having dual responsibility of managing work as well as household chores, non-working women reported poorer quality of life. It is argued that employment can have a role enhancement effect as well as role strain effect on the health of working women. ${ }^{11}$ The findings of this study suggest a role enhancement approach. Dwiwedi $A$ et al reported working married women to have better self-esteem, are well aware of their psychological 
needs and manage them well. ${ }^{12}$ Mehfooz $A$ et al used the WHOQOL-BREF questionnaire to assess quality of life and reported no difference in physical health between married working women and housewives, but both the groups differed with respect to psychological, social and environmental aspect. ${ }^{13}$ Riffat $S$ et al, however reported married working women to have more somatic as well as psychological problems due to dualreposnsibilities. ${ }^{14}$ A study done in Rajkot by Dudhatra $\mathrm{R}$ et al showed nonworking women to have better mental health unlike the findings of the present study. ${ }^{15}$ Suman VB et al used SF-36 to assess quality of life and reported working women to have poorer scores however, none of the values were found to be statistically significant. ${ }^{16}$ Harilal A also found stress levels to be higher among employed women compared to housewives and reported the family's financial position to play a key role. ${ }^{17}$ Saravi $\mathrm{F}$ also reported findings similar to the present study, i.e employed women scored higher than housewives in all measures except for physical functioning and the differences were found to be remarkable for vitality, mental health and role emotional. ${ }^{18}$

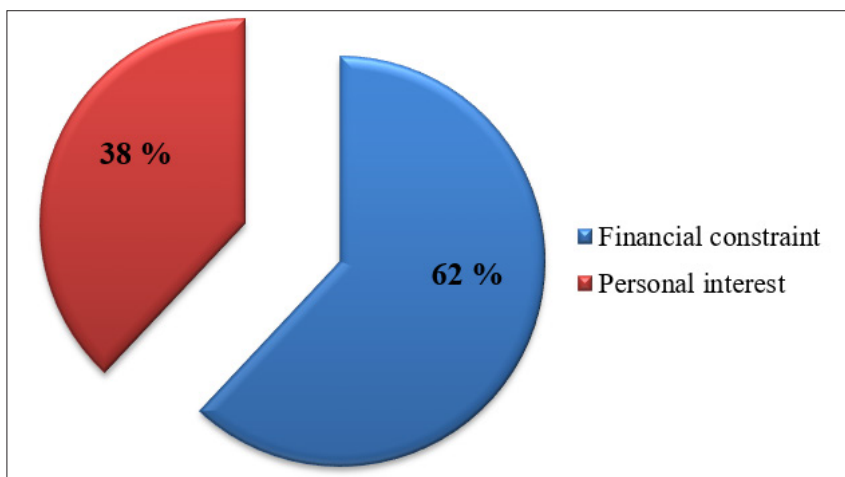

Figure I.Reasons for working as reported by working women $(\mathbf{N}=\mathbf{5 0})$

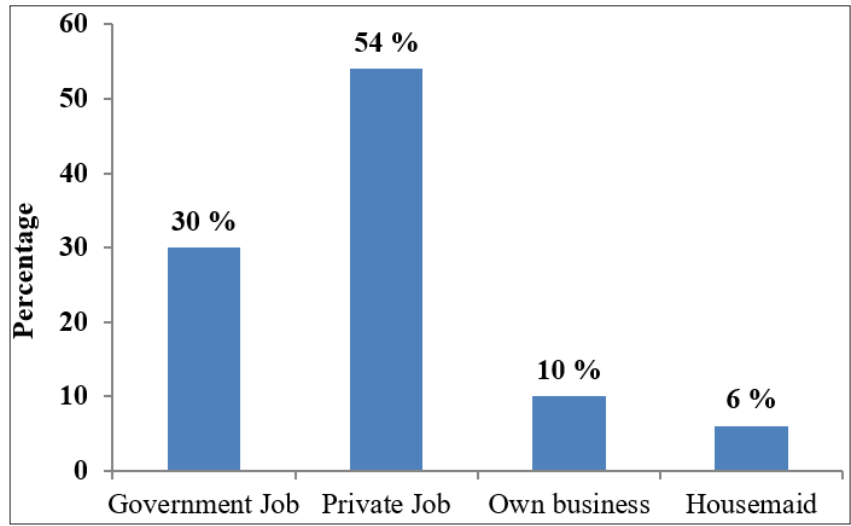

Figure 2.Type of work as reported by working women $(\mathbf{N}=\mathbf{5 0})$

\section{Conclusion}

Findings of this study suggest working women to have better quality of life. This may be due to a sense of self esteem, security and independence of a working woman. Employment and work provides women with opportunities to become self reliant and hence employment or work contributes to improvement of quality of life of women. Even though balancing work and household tasks remains a paramount challenge to many women, making work environment more flexible will encourage women to take up work and thus improve their quality of life.

Ethical Approval: The ethical approval was obtained from the Institutional Ethics Committee.

\section{Funding: None}

\section{Conflict of Interest: None}

\section{References}

1. R Balaji. Work life balance of women employees. IJIRSET 2010; 3(10): 16840-16843. Available from: http:// www.ijirset.com/upload/2014/october/63_work\%20 life\%20balance.pdf [Google Scholar].

2. Kumari V. Problems and challenges faced by urban working women in India [dissertation]. Odisha: National Institute of Technology; 2014.

3. Working moms healthier than full-time homemakers [Internet]. Scientific American. Available from: www. https://www.scietificamerican.com/article/workingmoms-healthier-th/Accessed 20 May 2017.

4. Health-Related Quality of Life (HRQOL) [Internet]. Centers for Disease Control and Prevention. Available at: https://www.cdc.gov/hrqol/. Accessed 20 June 2018.

5. WHOQOL: Measuring Quality of Life [Internet]. World Health Organization. Available from: www.who.int/ healthinfo/survey/whoqol-qualityoflife/en/. Accessed 20 May 2017.

6. Farlinger S: Quality of life for women. Soc Indicators Res 1996; 39(1): 109-119. Available from: https://link. springer.com/article/10.1007/BF00300835.

7. Shambunath B. Working women: a study on health status [dissertation]. Karnataka: Gulbarga University; 2015.

8. Mankani R, Yenagi G. Comparative study of mental health of working and non working women. J of Agr Sci 2012; 25(4): 510-513. Available from: http://14.139.155.167/test5/index.php/kjas/article/ view/6675 [Google Scholar]

9. Zalodiya K. A comparative study of mental health among working women and housewives. Int Mulitidisciplinary J 2013; 1(3): 57-58.

10. Working woman. Collins English Dictionary_Complete and Unabridged. $12^{\text {th }}$ Edition. Harper Collins Publishers.

11. RAND. 36-Item Short Form Survey (SF-36). Available at: www. Rand.org/health/surveys_tools/mos/36-itemshort-form/scoring.html. 
12. Reid J, Hardy M. Multiple roles and well-being among midlife women: testing role strain and role enhancement theories. J Gerontol B Psychol Sci Soc Sci 1999; 54(6): S329-S338. Available from: https://academic.oup. com/psychsocgerontology/article/54B/6/S329/577203 [PubMed/ Google Scholar]

13. Dwiwedi A, Srivastava A. A study of depression and self-esteem between working and non-working married women. Int J of Sci Research 2016; 5(5): 186-190. Available from: https://www.worldwidejournals. com/international-journal-of-scientific-research(IJSR)/article/a-study-of-depression-and-self-esteembetween-working-and-nonworking-married-women/ Nzk4NA==/?is=1.

14. Mehfooz A, Khan A. Quality of life among married working women and housewives. Int J of Eng and Techn 2018: 14-17. [ResearchGate].

15. Riffat S, Amena Z. Dual responsibility: a contributing factor to psychological ill-being in married working women. Academic Research J 2014; 5(2): 300-308. Available from: http://www.savap.org.pk/journals/ ARInt./Vol.5(2)/2014(5.2-33).pdf [Google Scholar].

16. Dudhatra R, Jogsan Y. Mental health and depression among working and non working women. Int J of Sci Research. 2012; 2(8): 1-3. Available from: http:// www.ijsrp.org/research-paper-0812/ijsrp-p0835.pdf [Google Scholar].

17. Suman VB, Chatterjee P. Psychological and physical wellbeing in working women. Int J of Med Sci and Pub Health 2015; 4(11): 1489-1492. Available from: http:// www.ijmsph.com/?mno=179944 [Google Scholar].

18. Harilal A, Santhosh V A. A comparative study on stress levels among working women and housewives with reference to the state of Kerala. NMIMS J of Economics and Public Policy 2017; 2(1): 31-35. Available from: https://epp-journal.nmims.edu/wp-content/ uploads/2017/april/a-comparative-study-on-stresslevels-among-working-women-and-housewives-withreference-to-the-state-of-kerala-harilal-a-santhosh-v-a. pdf [Google Scholar].

19. Saravi F, Navidian A, Rigi S, Montazeri A. Comparing health-related quality of life of employed women and housewives: a cross sectional study from South East Iran. BMC Women's Health 2012; 12: 41. Available from: https://bmcwomenshealth.biomedcentral.com/ articles/10.1186/1472-6874-12-41 [PubMed/ Google Scholar]. 